\title{
The effectiveness of the Millennium Development Goals (MDG) as global paradigm shift for poverty eradication in sub-Saharan Africa
}

\author{
H.J. VAN DER ELST.
}

\begin{abstract}
Despite isolated progress there seems to be no clear-cut guideline or solution to the collective eradication of extreme poverty in sub-Saharan Africa. In an attempt to overcome the above reality, the objective of the Millennium Development Goals (MDGs) is short term poverty relief to the poorest of the poor by 2015. This is to be achieved through the realisation of eight pro-poor objectives. Since 2000 there has been notable progress. Developmental organisations such as the World Bank, the International Monetary Fund (IMF) and the Freedom House Index project that global poverty will have been reduced to below fifteen per cent by 2015. The MDGs can, however, currently only be perceived as partially effective because poverty relief remains restricted to mainly Latin America and South and South East Asia. This partial success is substantiated by the reality that the majority of states in sub-Saharan Africa remains subjected to a cycle of extreme poverty, which seems impossible to overcome. There is consensus amongst many researchers that none of the MDGs will be achieved in this region by 2015 .

This article aims to critically analyse the nature, objectives and progress of the MDGs as a global developmental paradigm shift. In order to explore future trends and identify potential solutions, an emphasis is, however, placed on the possible reasons for the slow progress of the MDGs, specifically in sub-Saharan Africa.
\end{abstract}

Keywords: Global paradigm shift, new conditionality, extreme poverty, poverty eradication, sub-Saharan Africa, foreign aid, deprivation hypothesis, weak governance, free-market approach and the poverty trap.

Disciplines: International relations, law, political economy, politics, environmental studies, water studies, communication studies, public management and governance, education, sociology, anthropology and history.

\section{Introduction}

When the cold war ended it was believed that the western Rostovian growth path of economic and political liberalisation of poor states would guarantee development and prosperity. However, in many instances development initiatives in poor states seemed to fail. In the mid-1990s it was realised that a global change towards developmental thought was needed. This lead to the adoption of the Millennium Development Goals (MDGs) by the General Assembly of the United Nations (UN) in 2000. The adoption of the MDGs meant that there was a decisive paradigm shift in the international motivation and rationale behind

Dr Herman van der Elst is head of the subject group Political Science in the School of Basic Sciences at North-West University's Vaal Campus. Email: herman.vanderelst@nwu.ac.za. 
developmental thought and initiatives by developed states to developing states (UN 2010:14). In practice the paradigm shift translated into the replacement of the pre-2000 occupation with the (longer term) growth path of economic and political liberalisation of states, with the more immediate (shorter term) goal of extreme poverty eradication.

In achieving the goal of global poverty reduction there have been visible successes especially in the states of Latin America, as well as South and South East Asia. Examples are rising economic growth rates, better education, reduced child mortality rates, more access to drinking water and improved health services (World Bank 2011:6).

Despite these successes there remains an enormous poverty gap variation across, and between regions and states (Sachs et. al. 2004:121). Most importantly there still seems to be a concentration of extreme poverty and underdevelopment in many states of sub-Saharan Africa (Sachs et. al. 2004:121). Against the above contextual background, and in order to achieve the aim of this article, research was structured around the following four central themes:

- To elucidate on the essence of the MDG paradigm shift as a so-called new conditionality;

- To recognise the global value and successes of the MDGs;

- To identify and analyse the extent of, and possible reasons for the failure of the MDGs, in sub-Saharan Africa; and

- To provide a perspective and prognosis on the future unfolding of the MDGs, with a specific reference to the states of sub-Saharan Africa.

To achieve the above objective the article will be structured as follows. As a comparative background to the paradigm shift, the form and format of global developmental initiatives during the Cold war and Post Cold war dispensations will firstly be highlighted. Secondly, the link between poverty reduction and the MDGs, as well as the current development successes and failures in sub-Saharan Africa will be discussed. Thirdly, the focus of the article shifts to the positive and negative impact of foreign aid on the implementation of the MDGs in sub-Saharan Africa. Fourthly the article is narrowed down to the possible reasons for the current failure of the MDGs in sub-Saharan Africa. Here the deprivation hypothesis serves as explanatory foundation. It is argued that in contrast to South and South East Asia, prolonged deprivation in sub-Saharan Africa, lead to the cycle of MDG failure. An emphasis will be placed on weak governance and extreme poverty (or the so-called poverty trap) as causal framework for analysis. In conclusion contemporary and future trends towards the unfolding of the MDGs will be explored.

The form and format of development initiatives during the cold war and post-cold war dispensations (1945-2000)

During the Cold war the political and strategic pre-conditions behind development initiatives to developing states were aimed at promoting the ideological interest of either the United States of America (USA) or the former Soviet Union. It is widely documented that the provision of ideologically motivated development initiatives during this time frame, contributed to the underdevelopment and impoverishment of many states (Brown 2005:180181). For this reason the end of the Cold war translated into an era of international optimism in developing and developed states. It was believed that development initiatives could now (in 
the absence of ideological interferences) be channelled freely towards the democratisation of political systems and liberalisation of economies in need. Conditions for, for example foreign aid were now also linked to good governance, human rights and prescribed trade conditions (Uzor 2009 1-2). Since the end of the Cold war towards the end of the 1990s many developing states, especially those in sub-Saharan Africa, have, however, been subjected to a continued spiral of poverty and political, social and economic underdevelopment (Chen and Sapsford 2005:107). In the absence of the cold war, this continued downward trend can, according to Clegg and Mitchell (2010:1) be attributed to external factors such as:

- New western donor developmental priorities directed towards the upliftment of Eastern Europe and other former communist states;

- Economic inwardness and protectionism as a result of international trade block formation;

- A post $9 / 11$ pre-occupation with national security interest at the expense of poverty alleviation strategies; and

- A slowing down of donor commitments as a result of global financial downturns.

Internal factors that contributed to continued underdevelopment included, according to Uzor (2009:1) the following factors:

- Distrust towards western donors of assistance (foreign aid);

- Growing dependency as a result of limited alternative resources for development;

- Limited export commodities and vulnerability in the global financial crisis;

- High levels of foreign debt;

- Ethnic unrest and rising nationalism in receiver states; as well as

- The inability of developing states to build capacity to strengthen their international political and economic bargaining positions.

It is against the background of a continued impoverishment in many developing states, especially those in sub-Saharan Africa, that a new way of thinking started to evolve.

The evolution of a global paradigm shift towards poverty reduction

A number of influential events in the 1990s redirected international developmental policy debates towards the importance of poverty reduction. These events included amongst others the 1996 Organization for Economic Cooperation and Development (OECD) Development Assistance Committee (DAC) report entitled Shaping the 21 st century: the contribution of development cooperation, the publication of the World bank report titled Assessing aid in 1998 and the 2002 UN conference on Financing for development (in Mavrotas 2007:211). However, the most important event that entrenched a paradigm shift in developmental thought was, according to Isard (in Isard et. al. 2006:1), the adoption of the MDGs by the UN in 2000. Here the focus shifted decisively away from the liberalisation of economies and political systems as a core objective, to poverty eradication aimed at the poorest of the poor as a priority. 


\section{Poverty reduction as the essence of the MDG paradigm shift}

The essence of the MDG paradigm shift is the belief that poverty reduction provides the foundation for further development. Once the basic needs of the poor in a developing state have been satisfied through poverty reduction, a solid platform has been created for continued democratisation and the liberalisation of political and economic systems (Sachs 2006:3). This combination of short term poverty reduction as a condition for effective democratisation and liberalisation would also encourage good governance and contribute to the integration of developing states into the global economy.

What makes the MDGs significant is that they are primarily focused on short term poverty reduction, they are time bound (2015) and have quantifiable targets. To Sachs (2006:1) the value of the MDGs can be found in its integral link with the Universal Declaration of Human Rights. They (the MDGs) represent the essence of basic human rights as agreed upon by the UN in 1948 and reaffirmed in Vienna in 1993 (Djonovich 1973:135-143). The 1993 declaration restipulated that all human beings are entitled to a humane existence with access to basic survival mechanisms such as housing, water sanitation, medical facilities, basic education, food and security (Fiddelaar and Van Meppelen Scheppink 1998:12). Sachs (2006:1) defines the MDGs as follows:

"Time bound and quantified targets for addressing extreme poverty, in its many dimensions income poverty, hunger disease, lack of adequate shelter, and exclusion-while promoting gender equality, education and environmental sustainability".

From a holistic perspective the MDGs are a set of internationally agreed upon targets to globally improve the wellbeing of the poor (ensure poverty reduction) in developing states by 2015. Its main objectives are state specific and can be summarised as follows (United Nations 2010 4-8 and Burnell and Randall 2008:524):

- The eradication of extreme poverty;

- Achieving universal primary education;

- The empowerment of women;

- Reducing child mortality;

- Improving maternal health;

- Combating HIV/AIDS and other deceases;

- Ensuring environmental sustainability; and

- Developing global partnerships.

It is expected of the developed and developing states to put mechanisms in place in order to ensure the effective implementation of the MDGs.

\section{Linking the MDGs and poverty reduction as global developmental objective}

As indicated, the eradication of poverty as opposed to cold war and post cold war motivations is the primary objective of the MDGs. The most commonly used method of defining, establishing and measuring levels of poverty, relates to an individual's income. According to the World Bank annual report (2011:14) an individual is exposed to extreme poverty if he/she 
earns less than $\$ 1,25$ per day. The international concentration of poverty per region based on this monetary criterion can be summarised as follows (see table 1).

\begin{tabular}{|l|l|l|l|}
\hline Region & $\begin{array}{l}\text { Percentage of } \\
\text { the population } \\
\text { living on less } \\
\text { than } \$ 1.25 \text { a day }\end{array}$ & $\begin{array}{l}\text { Population in } \\
\text { millions }\end{array}$ & $\begin{array}{l}\text { Number of people in } \\
\text { millions earning less } \\
\text { than } \$ 1.25\end{array}$ \\
\hline East Asia and the Pacific & 16.8 & 1.884 & 316 \\
\hline Latin America and the Caribbean & 8.2 & 550 & 45 \\
\hline South Asia & 40.4 & 1.476 & 596 \\
\hline Sub-Saharan Africa & $\mathbf{5 0 . 9}$ & 763 & 388 \\
\hline Europe and central Asia & 0.04 & 473 & 17 \\
\hline Middle East and North Africa & 0.04 & 305 & 11 \\
\hline
\end{tabular}

Table 1: Regions of extreme poverty in the world Source: World hunger education service 2011:8 and World Bank 2011:24

From the above illustration it is clear that, in terms of percentage, the majority of people still subjected to extreme poverty lives in sub-Saharan Africa. Although levels of income are a strong indication of poverty levels Gordon (2005:3) and Burnell and Randall (2008:318) are of the opinion that this monetary definition, criteria and illustration is too narrow to measure extreme poverty. Poverty is multidimensional and subjected to a variety of overlapping social, economic and environmental interpretations, definitions, circumstances and events which must be taken into consideration simultaneously (see figure 1).

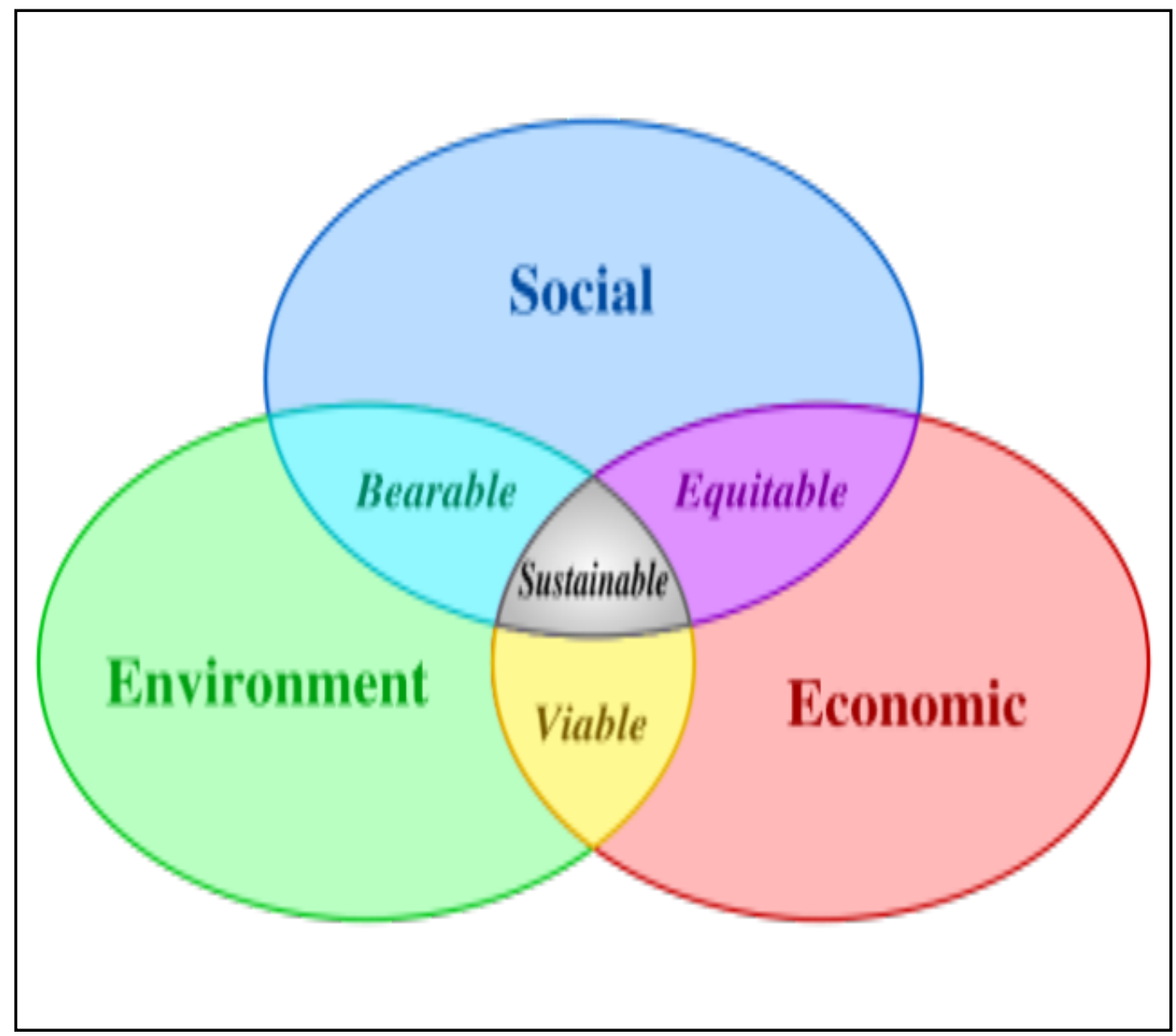


Figure 1: The requirements for sustainable development. Source: Report on the United Nations Conference on the Environment 2005:11-12

Annual income remains an import instrument to point to poverty but it cannot be regarded as the only means of measurement. Together with a variety of other indicators, life expectancy, deaths per thousand births and access to flush toilets are just three examples of factors (resorting under the MDGs) pointing to need, and poverty in a region (in this case subSaharan Africa) (see table 2).

\begin{tabular}{|l|l|l|l|}
\hline Region & $\begin{array}{l}\text { Life expectancy } \\
\text { at birth }\end{array}$ & $\begin{array}{l}\text { Under five } \\
\text { mortality rate } \\
\text { (Deaths per 1000 } \\
\text { births) }\end{array}$ & $\begin{array}{l}\text { Access to flush } \\
\text { toilets } \\
\text { (percentage) }\end{array}$ \\
\hline East Asia and the Pacific & 70.2 & 19 & 56 \\
\hline Latin America and the Caribbean & 70.6 & 23 & 69 \\
\hline South Asia & 62.6 & 69 & 36 \\
\hline Sub-Saharan Africa & 46 & $\mathbf{1 2 9}$ & $\mathbf{3 1}$ \\
\hline Europe and central Asia & 77 & 7 & 95 \\
\hline Middle East and North Africa & 68.4 & 26 & 89 \\
\hline
\end{tabular}

Table 2: Selected social and environmental development indicators. Source: Millennium development goals report 2011:25 and 55

Other measurement criteria which point to poverty in sub-Saharan Africa are, for example, the extent of undernourishment, gender ratio in access to education, maternal mortality, access to water and percentage of population living in slums etcetera (Sachs 2006:19).

In order to acknowledge the necessity of sustainable development as objective of poverty reduction, the scope of research is narrowed down to the following holistic UN definition of poverty (Gordon 2005:3). This definition serves as interpretative guideline and measure instrument for the effectiveness of the MDGs:

"Fundamentally poverty is a denial of choices and opportunities, a violation of human dignity. It means a lack of the basic capacity to participate effectively in society. It means not having enough to feed and clothe a family, not having a school or clinic to go to; not having the land on which to grow one's food or a job to earn one's living, not having access to credit. It means insecurity, powerlessness and exclusion of individuals, households and communities. It means susceptibility to violence, and it often implies living in marginal or fragile environments, without access to clean water or sanitation".

The link between poverty reduction and the MDGs can be found in the entrenchment of the fifteen year commitment and partnership between developed and developing states to uplift the poorest of the poor in the world. In other words, it represents a step towards the eradication of poverty. With reference to concrete implementation practices, the MDGs can be described as an individualised approach aimed at specific states and outcomes (Burnell and Randall 2008:524). They are about satisfying basic needs and ensuring economic and social rights specifically for people in developing states (Sachs 2006:3). The planned outcomes of the MDGs were founded in the belief that short term poverty reduction in developing states improves living conditions, can lead to social upliftment and can save millions of lives. In other words poverty reduction has the potential to immediately improve the lives the poor. 
The agreed upon responsibilities of the developed and the developing states towards achieving the MDGs and poverty reduction

In terms of its concrete implementation, the MDGs are a state-specific approach and culminate in a two-way agreement between developed and developing states. Gould (in Evans 2006:373) refers to this approach as a so-called post-2000 "new conditionality". It has the primary objective of poverty eradication, but it also wants to influence policy and decision making processes in receiver states. This boils down to the creation and maintenance of a stable social, political and economic environment conducive to the success of the MDGs.

The new conditionality can be summarised as follows. Without being prescriptive, developed states committed themselves to the achievement of the MDGs through the channelling of foreign aid, technical expertise, advice and other expertise as needed to developing states (Economist print edition 2010b: 5-6). In turn developing states committed themselves to good governance, economic growth and local ownership (Randall and Burnell 2008:300). In the process they must identify and prioritise their domestic needs. It is also expected of the developing states to identify specific problem areas within the framework of the MDGs. This means that the developing state must take the lead in designing a state specific national development strategy to overcome these challenges.

\section{A perspective on the post-2000 successes of the MDGs}

As an outcome of the developmental initiatives, poverty eradication is now perceived as the foundation for the realisation of economic growth and continued democratisation. It is therefore important that the MDGs culminated into concrete and measurable successes. In many respects it is clear that there has been significant progress. In terms of global poverty reduction there have been measurable and concrete successes. The UN for example predicts that absolute poverty could be reduced from $46 \%$ in 1990 to $15 \%$ by 2015 (World Bank 2011:6). States such as China, India and others in South and South East East Asia experienced high levels of economic growth, thus significantly reducing levels of international poverty (United Nations 2010:2).

According to the Millennium Development Goals Report (2011:6-7) the following global noteworthy successes have been achieved in developing states since 2000:

- The average income of people in developing states increased by approximately $21 \%$;

- People subjected to extreme poverty declined by an estimated 130 million;

- Child mortality rates fell from 103 deaths to 88 deaths per 1000 live births;

- An additional 8\% of people in the developing world gained access to clean water; and

- An additional $15 \%$ of people in the developing world acquired access to improved sanitation services.

Despite the successes the above statistics are misleading because there remains an enormous poverty gap variation across, and between regions and states. The reality is that only forty nine out of eighty seven states are within reach of achieving the poverty reduction target (World Bank 2011:6). For example in South and South East Asia 17\% of the population currently lives in absolute poverty. In contrast $51 \%$ of the population of sub-Saharan Africa 
lives in absolute poverty (World Bank 2011:6-7). Despite the progress and global optimism, the achievement of the MDGs in sub-Saharan Africa is marginal, and in many instances even failing (Brown 2009:1 and Isard (in Isard et al 2006:1-3). Chen and Sapford (2005:298) view sub-Saharan Africa as the most marginalised region in the world and the only continent where poverty is rising and where the MDGs will probably not be achieved by 2015 .

\section{A perspective, and comparative overview on the post 2000 extent, and failure, of the MDGs in sub-Saharan Africa}

In comparison to other developing regions, the majority of states in sub-Saharan Africa are lagging in all the objectives as earmarked through the adoption of the MDGs. According to the development criteria of the Freedom House Index thirteen of the thirty five least developed states in the world are situated in sub-Saharan Africa. This includes states such as Zimbabwe, the Ivory Coast, Cameroon, the Congo, Gabon, Senegal, Tanzania, Uganda etcetera (McCormick 2007:370, 495). In essence this category of states shares, according to McCormick, (2010:419 the following shortcomings:

- A mixed record on representative government;

- Weak political institutions and processes;

- Limited public loyalty to the state;

- Ineffective democratic institutions;

- Inability to constantly protect individual human rights;

- Limited or absence of political opposition;

- Low per capita income with economies based on agriculture;

- Low levels of urbanisation and poor infrastructure;

- Low technological development;

- Inadequate education, health care and other basic services; and

- Minimum global influence.

In order to create an environment conducive to the success of the MDGs these shortcomings must be overcome. The following key reasons and indicators in underdevelopment in subSaharan Africa in comparison with other more successful regions emerged, and can be summarised under the following rubrics discussed below.

Poverty reduction and economic growth

Between 1960 and 2005 the economies of states in South and South-East Asia grew at an average rate of $6 \%$. This also coincided with a simultaneous decline in population growth. As a result of this, the number of people in the world that lives on less than $\$ 1,25$ per day has been halved. However, in sub-Saharan Africa economies grew with only 3.5\% in the same timeframe. Consequently $46 \%$ of the population in sub-Saharan Africa still lives on less than $\$ 1,25$ per day. This in turn coincided with a population explosion which almost nullified the benefits of economic growth. In this region more than half of the population is still living in extreme poverty and little progress has been made in terms of providing people with access to basic food resources (Van Donge et. al. 2010:2). 
Access to and quality of education

Since 1999 the number of children enrolled in primary schools worldwide rose by more than 40 million and international aid commitments to basic education almost doubled from $\$ 2.1$ billion in 2002 to $\$ 4.1$ billion in 2007 . Net primary enrolment in sub-Saharan Africa also rose from $58 \%$ to $74 \%$. However, in sub-Saharan Africa about one third of the learners do not complete primary education. The average completion rate for primary education is less than 50\% (Sachs 2006:23). In addition the MDG strategy is that the empowerment of women must coincide with achieving the objective of universal primary education. In subSaharan Africa gender inequality in primary education is still the highest in those regions with lowest enrolment. This indicates that where families cannot send all their children to primary school, they tend to send the male learners (Glegg and Mitchell 2010:2).

\section{Child mortality and gender equality}

In North Africa the child mortality rate has thus far been reduced by two thirds. In subSaharan Africa the mortality rate is 920 deaths per 100000 births (Sheperd 2008:2). One in every seven children in sub-Saharan Africa still dies before their seventh birthday. In addition, one in every hundred births in sub-Saharan Africa still causes the death of the mother (world development movement 2010:3).

\section{Rate of HIV infections}

Globally the rate of new HIV infections started to decline due to the fact that antiretroviral drugs have become more freely available. The treatment in sub-Saharan Africa has also tripled but the drugs are still reaching less than half of those in need. The decline in life expectancy is also linked to the spread of the AIDS epidemic in the region (Van Donge et.al. 2010:3) According to Sachs (2006:25) and the Millennium Development Goals Report (2011:37) AIDS or HIV infections is currently affecting between 23 and 40 million people in this region.

\subsection{Access to water and sanitation}

Between 1990 and 2006 the proportion of people without proper sanitation dropped worldwide by eight per cent. In sub-Saharan Africa only one third of the population has access to proper sanitation (Sheperd 2008:1). All regions, with the exception of sub-Saharan Africa, have met the goal of halving the proportion of people without drinking water.

In recognition of the slow progress and even failure of the MDGs in sub-Saharan Africa, the 2005 G8 recommitted the developed states to the continued provision of appropriate aid.

\section{The impact of foreign aid on the realisation of the MDGs: the Gleneagles agreements}

According to the Sheperd (2008:1) the success or failure of the MDGs will have immense consequences, not only for poverty eradication in many states but also for the future credibility of the collective action efforts of the international community. In recognition of the importance of the MDGs and the success thereof in sub-Saharan Africa, the 2005 G8 summit took place in Gleneagles (Scotland). An important foundation of the summit was the acknowledgement that underdevelopment in sub-Saharan Africa is continuing, and that poverty reduction in this region must now be a priority if the MDGs are to be met by 2015 . The key message of the summit was therefore "putting Africa back on the agenda" 
(Gleneagles 2007:1). With reference to poverty reduction (in specifically sub-Saharan Africa) the following has been agreed (Ndungane 2006:3 \& Besada and Mcmillan 2010:1):

- That aid to specifically Africa be doubled to $\$ 50$ billion per annum by 2010 , half of which should go to sub-Saharan Africa;

- That aid budgets of the rich states should be increased by $0.56 \%$ of the Gross Domestic Product (GDP) by 2010 of the developed states. In 2015 it must already have reached $0,7 \%$, if the $\mathrm{MDG}$ are to be met;

- The cancellation of foreign debt to the value of $\$ 40$ billion to 18 of the world's poorest states of which the majority are in sub-Saharan Africa;

- That AIDS treatment be made free;

- The provision of universal access to free primary education and health care;

- Increase debt write-offs to the 62 poorest states in the world; and

- Review trade barriers limit protectionism in order to make trade conditions and access to external markets for developing states more favourable.

In essence the Gleneagles agreements therefore recommitted the developed states to the provision of foreign aid directed towards poverty reduction. It was now, however, agreed that a specific emphasis must be placed on the needs of sub-Saharan Africa. The idea is that this aid commitment must also coincide with improved market access through the reduction of protectionist trade relations and barriers of developed.

\section{The successes of the Gleneagles agreements in sub-Saharan Africa}

Debt relief to sub-Saharan Africa is a Gleneagles initiative that has been effective. In many instances it resulted in significant gains and has provided capital to invest in poverty reduction strategies (Vyas-Doorgapersad 2010:45). For example, the Multilateral Debt Relief Initiative (MDRI) was launched in 2005 at the Gleneagles summit and is an addition to the Heavily Indebted Poor Countries Initiative (HIPC) launched in 1996. The HIPC provided relief or debt cancellation to states that showed signs of good governance. The purpose of the MDRI is to provide additional debt relief to states that utilised the HIPC effectively. States in sub-Saharan Africa who qualified for this arrangement were Benin, Burkina Faso, Cameroon, Ethiopia, Ghana, Guyana, Madagascar, Mali, Mauritania, Mozambique, Niger, Rwanda, Senegal, Tanzania, Uganda and Zambia (Africa action 2010:14). In many of the above states governance has improved and debt has been relieved to such an extent that expenditure could now be directed towards investment in the MDGs and poverty reduction.

\section{The failure of the Gleneagles agreements in sub-Saharan Africa}

Despite the Gleneagles successes there is are still a variety of problems hampering the implementation of the MDGs in impoverished states. These problems are mainly linked to the lack of commitment to foreign aid agreements by individual developed states (Economist print edition 2010a:2-3). The practical implication is that states in sub-Saharan Africa are not receiving the agreed upon amounts of money towards the realisation of the MDGs. As indicated the objective was to double foreign aid to developing states and increase the percentage donated by individual developed states to 0.7 by 2015 . Aid to sub-Saharan Africa 
has, however, only increased by $3 \%$ and in 2009 the average figure of foreign aid allocation as divided amongst the EU states was only $0.42 \%$ (see figure 2 ).

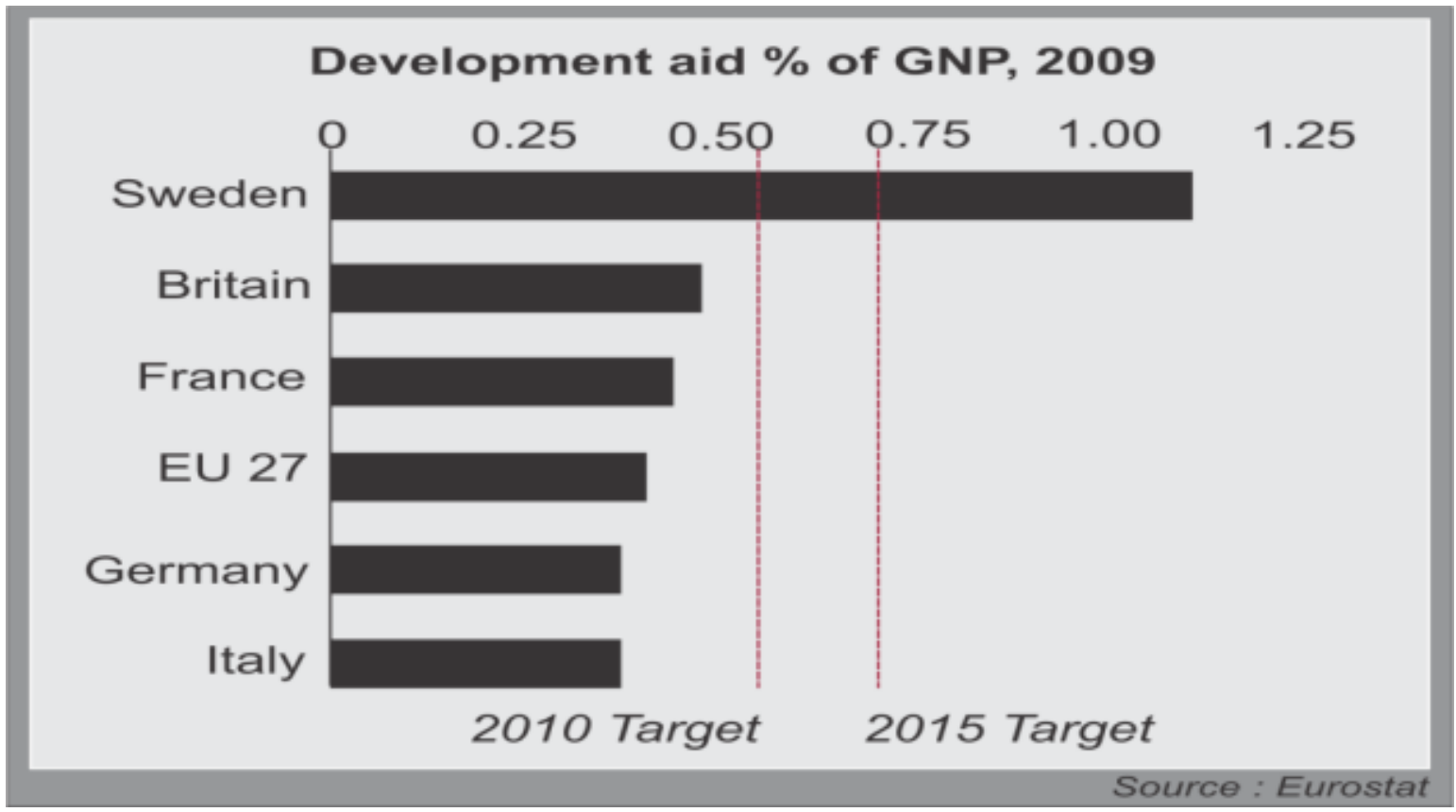

Figure 2: The growth of development aid to sub-Saharan Africa. Source: Economist print edition 2010a:2-3

In the United States of America (USA), Canada and Japan the figure of foreign aid donated to sub-Saharan Africa currently stands on respectively $0.22 \%, 0.34 \%$ and $0.28 \%$ (McCormick 2007:494). This lack of commitment can be linked to the prioritisation of the national selfinterest of donor states (Economist print edition 2010a:2-3). There tends to be an increased donor focus on other internal and external challenges such as the global impact of an international recession, control of illegal immigration, curbing international terrorism, protection of markets, prioritised trade relations, regional security etcetera.

The deprivation hypothesis as an explanation for the failure of the MDGs in the states of sub-Saharan Africa

In many sub-Saharan Africa states the public and civil layers of society are so impoverished that they are, despite foreign aid, simply not able to implement the MDGs. The so-called deprivation hypothesis has been identified by Kahl (2006:8) as a key causal factor for the failure of the MDGs in these states. Davies (in Jackson and Jackson 2003:427) agrees and views deprivation as the main cause of the mass mobilisation of a society which can in turn lead to political instability.

The hypothesis revolves around scarcity due to prolonged multiple deprivations. Scarcity refers to the absence of an ability to invest in the public and civil structures of a society. The effectiveness of the MDGs depends on, for example, investment in human and natural resources, knowledge and technical expertise, rural development, the environment, industry, health, education, infrastructure, economic growth etcetera (Sachs et.al. 2004:122 and Jackson and Jackson 2003:428). 
In the absence of a combination of ${ }^{1}$ good governance and the eradication of extreme poverty, a state will be vulnerable to political turmoil and instability as well as the failure of key governance mechanisms. Davies (in Jackson and Jackson 2003:428) and Davies (1959:282) is of the opinion that a prolonged scarcity (absence of good governance and poverty reduction) in a society can lead to an intolerable deprivation gap. In other words there is a gap between expected need satisfaction and actual need satisfaction. As the gap widens it becomes intolerable and can cause political instability and in the worst case scenario a violent replacement of a government (Goodwin 2007:103) (see figure 3).

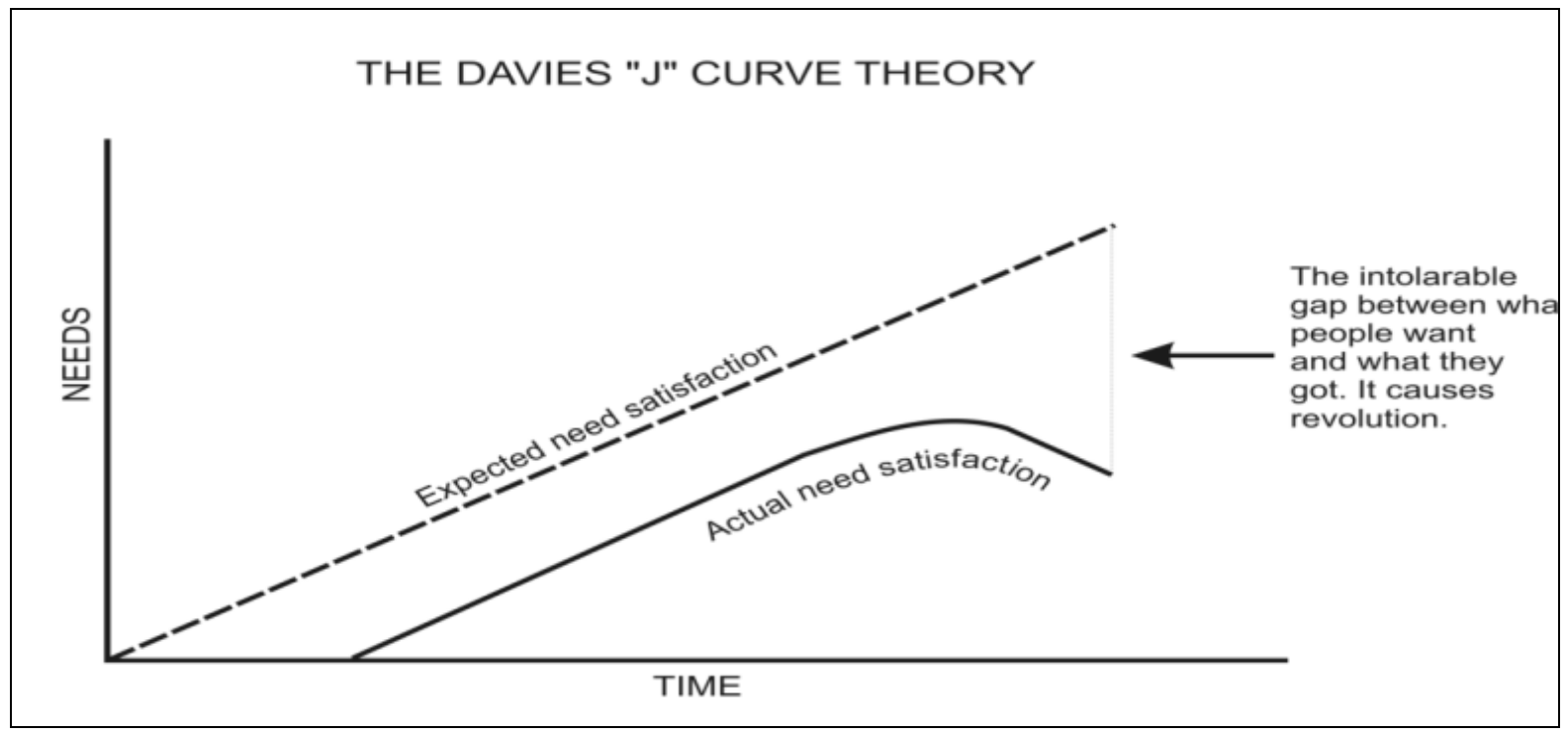

Figure 3: The deprivation hypothesis and scarcity. Source: Jackson and Jackson 2003:428 The following trends occurring in states subjected to deprivation are identified by Sachs (2006:38) and Kahl (2004:9):

- An uncontrolled population explosion in rural areas;

- Environmental degradation and damages to natural resources;

- Unequal distribution of natural resources;

- A so-called brain drain where skilled workers leave the impoverished state;

- Low foreign investment;

- Low innovation and an inability to invest in science and technology;

- A low savings rate and limited access to effective banking facilities;

- Low and irregular tax income, restraining government investment in the public sector;

- Limited, or even the absence of foreign investments; and

- The mass emigration of skilled works.

Good governance has eight characteristics namely: being participatory; consensus orientated; accountable; transparent and responsive; effective and efficient; equitable and inclusive; follows the rule of law; takes into account the views of minorities and the vulnerable; and is responsive to the present and future needs of a society. Source: UNESCAP 2012:1-3 
In order to avoid deprivation, receiver states needs to be committed to good governance and the eradication of extreme poverty (Sachs et. al 2004:121-121). In the following section the reasons for the absence of an environment conducive to the success of the MDGs in subSaharan Africa are being holistically discussed.

\section{The inability of sub-Saharan African states to duplicate the development models of South and South East Asia}

In many developed and developing states stimulating economic growth is still seen as the main way to reduce poverty. This belief was founded in the role model provided by strong patterns of sustained economic growth that occurred in some states in South and South East Asia during the past three decades (Sheperd 2008:43). In terms of developmental challenges the states of sub-Saharan Africa are unique and differs from those in South and South East Asia. The South and South East Asian role model should, and can therefore not be duplicated. It can however be assumed that some patterns of economic growth in the region should be followed in order to stimulate poverty reduction in sub-Saharan Africa. A major characteristic of the current sustainable growth in South-and South East Asia was the format of simultaneous state intervention towards poverty reduction and development (Van Donge et al. 2010:1). Firstly, there was a pro-active combination of measures to ensure macroeconomic stability. Secondly, policies towards improving life in the rural sector, increasing agricultural productivity and ensuring an ample supply of food, were institutionalised and implemented. Thirdly, initiatives towards liberalising the economy and creating conditions of economic freedom for specifically subsistence farmers were implemented (Van Donge et al. 2010:1). Therefore the simultaneous and interlinking format of state intervention was profree market, pro-political stability and pro-poor.

The states of South East Asia were able to create an economic, social and political environment that was conducive to the implementation of the MDGs. As a result of prolonged deprivation many states in sub-Saharan Africa were characterised by weak governance and a continuous cycle of extreme poverty. They were too politically unstable and impoverished to duplicate the development models of South and South East Asia, and creating an environment conducive to the success of the MDGs.

\section{Weak governance: the consequences of the absence of the rule of law in the states of sub-Saharan Africa}

As previously indicated, the long term developmental objective of the MDGs is the successful democratisation of political systems and the liberalisation of economies in developing states. As a precondition for success it is assumed by developed states that all participants want to establish a liberal democratic society. As a step towards achieving this objective, short term poverty relief to the poorest of the poor became a first priority of the MDG paradigm shift (Sachs 2006:29). According to Kaufman (2010:9) the success of the MDGs is, however, highly dependent on effective governance. For the MDGs to succeed a government must therefore at least be committed to good governance. In other words government and civil society institutions must be structured in such a way that a relationship and culture of trust, accountability and effective management are entrenched in order to ensure responsible governance (Kaufman 2010:10). Good governance or a commitment to good governance is 
therefore necessary if a state wants to create, provide and maintain pro-poor services and infrastructure (Burnell and Randall 2008:322). Iqbal and Shah (2008:3) view governance as a set of traditions and institutions through which a country is governed. Good governance depends on the effectiveness of the following processes:

- The way in which governments are selected and replaced;

- The ability of a government to formulate and implement sound policies; and

- The extent to which a government can entrench stable relations between civil society and the state in terms of economic and social interaction.

A key ingredient for the establishment of a liberal democratic society is the presence of the rule of law (Sachs 2006:29). Heywood (2007:326) defines the rule of law, and its purpose, as follows:

"It is the principle that the law should rule in the sense that it establishes a framework to which all conduct and behaviour conform, applying equal to all members of a society, be they members of civil society or government officials".

The essence of the rule of law is therefore that a society must be governed by general judicial principles and not the arbitrary actions or decisions of individuals (Kotze and van Wyk 1986:117). There must be a relationship of trust, transparency and accountability between a government and its population. In a democratic dispensation the basic foundations of the rule of law entail, according to Sachs (2006:31) the following arrangements:

- Establishing effective mechanisms to ensure accountability and predict government behaviour;

- Guaranteeing human rights, stability and absence of violence;

- Transparent and honest relations between government and its citizens;

- Supporting organisations in civil society; and

- Control of corruption.

In many sub-Saharan African states the government institutions that must establish and maintain these basic principles are ineffective or absent (Sheperd 2008:2). Examples of these states are Zimbabwe, Angola, Democratic Republic of the Congo, Liberia and Sierra Leone.

It must, however, also be acknowledged that many states in sub-Saharan Africa are well governed. According to the World Bank, indicators states such as Benin, Burkina Faso, Ghana, Malawi, Mali, Mauritania, Senegal and Madagascar received a good governance grading (Sachs 2006:147 and World bank 2011:14). The failure of the MDGs can therefore not only be attributed to governance failures, but also to the extent of levels of poverty in individual states (World Bank 2011:6 and Sachs et. al. 2004:12). In other words, the failure of the MDGs can only be understood and explained through an analysis of the combination of weak governance and levels of extreme poverty in many states. 


\section{Extreme poverty inhibiting the development prospects for sub-Saharan Africa (the poverty trap)}

Good governance within developing states is essential for the achievement and success of the MDGs. According to Clemens and Moss (2005:1-2) good governance must, however, also be accompanied by accelerated economic growth. If these two elements are not present the MDGs will fail (Clemens and Moss 2005:1-2). The reality is that many states in subSaharan Africa are governed well but are simply too poor to make sufficient progress toward economic growth and achieving the set objectives of the MDGs. In states such as Zimbabwe, Angola, the Democratic Republic of the Congo (DRC), Liberia and Sierra Leone poverty seems to be rising. These states are so poor that policy reform or good governance alone will not ensure the effectiveness of the MDGs (Kahl 2004:6-8).

States are unique entities in terms of their political, social, economic and demographic composition. When exposed to extreme poverty they, according to Randall and Burnell (2008:318) and Sachs et.al (2004:120-123), however, share common social defining characteristics (trends) which point to multiple deprivation:

- A rising infant mortality rate;

- High levels of illiteracy ;

- Life expectancy of below fifty years;

- Undernourishment;

- Environmental degradation;

- Limited access to clean water and sanitation; and

- Absence of effective health services.

The above trends occur in the absence of investment in the following forms of capital:

- Human development;

- Private sector investment;

- Infrastructure development;

- Natural resources;

- Institutional capacity; and

- Knowledge.

Sachs (2006:4) refers to the above exposure to extreme poverty, as a so-called "poverty trap" and "poverty that kills" (see figure 4). It is a counterproductive re-occurring cycle of events that seems to entrench poverty, and is almost impossible to overcome. The Investopedia (2012:2) defines the poverty trap as follows:

A mechanism which makes it very difficult for people to escape poverty. A poverty trap is created when an economic system requires a significant amount of various forms of capital in order to earn enough to escape poverty. 


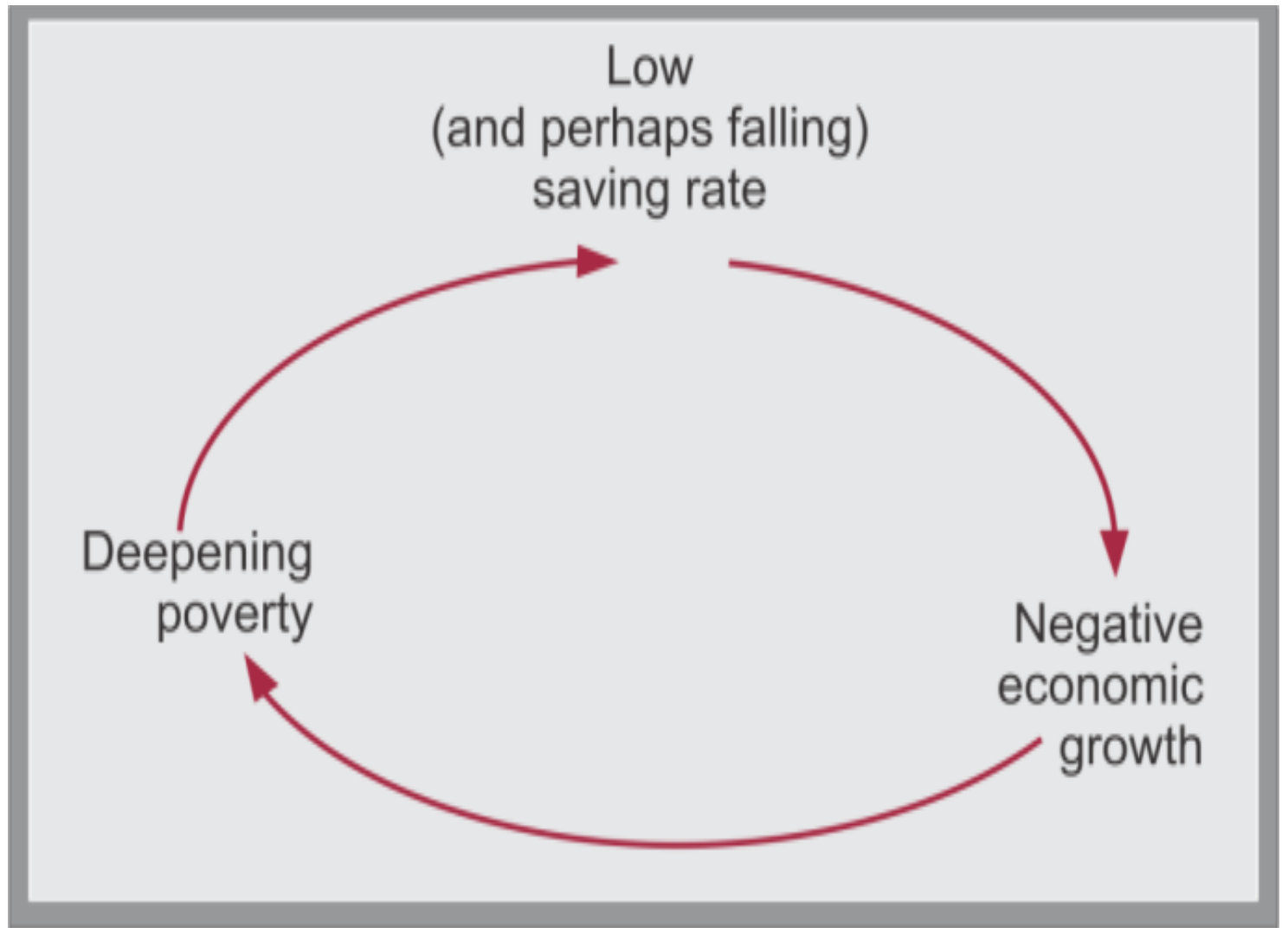

Figure 4: The poverty trap entrenching a cycle of underdevelopment. Source: Sachs 2006:36

As a result of extreme poverty, an inability exists to save and generate funding for the development of the necessary pro-poor structures to ensure the success of the MDGs. The practical implication is that governments are unable to invest in tarred roads, effective transport, soil nutrients, the provision of electricity, safe cooking devices, health services and education (Sachs 2006:34). Populations remain chronically hunger and exposed to diseases. According to Kahl (2006:9-10) this inability to save and invest in the infrastructure can in turn erode the gains made by good governance. For this reason many states cannot overcome impoverishment despite various forms of foreign involvement.

\section{Findings and recommendations}

The findings of this article confirmed that the MDGs materialised as a paradigm shift in global developmental thought. The main objective of developmental initiatives is short term poverty relief to the poorest of the poor. The MDGs have, however, only been partially effective. Poverty eradication remains restricted to the states of Latin-America, and South and South East Asia. In terms of a prognosis the article established that the majority of states in sub-Saharan Africa remains subjected to extreme poverty (a poverty trap). It seems clear that most of the MDGs will not be met by 2015. The article indicated that the main reasons for the continuation of poverty in this region revolve around the following main realities: 
- The absence of committed and appropriate foreign aid;

- Prolonged deprivation;

- Weak governance; and

- The poverty trap.

In order to overcome poverty and achieve the objective of the MDGs the structural recommendations of the article can be summarised as follows. This recommendation can be used as planning guidelines for both developed and developing states:

- The qualified implementation of the success model followed in South and South East Asia. The unique needs and circumstances of states in sub-Saharan Africa must, however, be taken into consideration. This must lead to an accelerated economic growth rate;

- Developing states must design a national development strategy by consulting foreign and domestic expertise. This would typically include developmental organisations linked to the achievement of the MDGs;

- Ensuring political, economic and social stability in order to create an environment that is conducive to the effectiveness of the MDGs (good governance and the rule of law);

- Overcoming the poverty trap through the promotion of a culture of saving and the correct utilisation of available funding (eradicating extreme poverty).

- Developed states must be committed to planned assistance, availability of enough foreign aid, not be prescriptive and aid must be directed to developing states that are impoverished and in need; and

- There must be development communication, cooperation and coordination between developmental organisations, developed and developing states.

In order to integrate the above guidelines into national development strategies it must be realised that poverty in sub-Saharan Africa is a multidimensional and complex phenomenon. There cannot be a uniform and clear cut model on how to overcome the poverty trap. Each case (state) is subjected to its own internal and external merits, unique circumstances and challenges. Vyas-Doorgapersad (2010:40) agrees and recommends that impoverished states must design an own national development strategy that is state-specific and pro-active enough to achieve the MDGs. Easterly (2007:4) is also of the opinion that the success of the MDGs depends to a great extent on the initiatives and will of the impoverished states themselves.

Although there is no uniform model for success, there can be a universal framework within which poverty reduction can be achieved. Easterly (2007:3-5) is of the opinion that the free market and state intervention must be the universal framework within which national development strategies can be formulated. A so-called laissez faire approach can, however, not be followed. According to Easterly (2007:4) many states are so impoverished that neither a strict free-market approach nor heavy handed state intervention will ensure success. In other words the implementation of these two extremes of the development spectrum will not ensure success. A strict free-market approach will lead to excessive competition and the exclusion of the poor whilst too much government intervention can inhibit private initiative, 
competition and eventually, economic growth. This means that the successful implementation of the MDGs could be achieved through a combination of a free market approach combined with responsible government intervention. Through this combined approach economic growth could be ensured and resources channelled to the poor in a responsible manner.

\section{Bibliography}

Africa action: Activism for Africa SINCE 1953. 2010. The millennium development goals: Progress in sub-Saharan Africa. http://africanaction.org/1/post/2010/03/the-progress-insub-saharan-africa.html Date of access: 20 Oct. 2010.

Besada, H., Mcmillan, L. 2010. Reaching success or reaffirming failure. http://www.cigionline.org/articles/2010/07/reachingsuccess or reaffirming failure Date of access: 20 Feb. 2011.

Brown, S. 2005. Foreign aid and democracy promotion: Lessons from Africa. The European journal of development research, 17(2): 179, June.

Burnell, P., Randall, V. 2008. Politics in the developing world. Oxford: Oxford University press.

Cleg, N., Mitchell, A. 2010. Assessing the progress towards the millennium development goals-goal by goal. http://www.wdm.org.uk/news/Assessing-progress-towards-milleniumdevelopment-goals.html Date of access: 22 Oct. 2010.

Clemens, T., Moss, T. 2005. Center for global development: What's wrong with the millennium development goals. www.cgdev.org Date of access: 23 Feb. 2011.

Chen, J., Sapsford, D. 2005. Global development and poverty reduction. Cheltonham: Edward Elgar publishing limited.

Davies, J. 1959. A formal interpretation of the theory of relative deprivation. Sociometry. 22 (4): 280-295, December.

Djonovich, D. J. 1973. United Nations resolutions: Universal declaration of human rights. New York. Oceana.

Earsterly, W. 2007. Africa's poverty trap. http://economistview.typepad.com/economistview/2007/03/william_easterl.html Date of access: 3 Mar. 2012.

Economist print edition. 2010a. Waylaid: Exuberant promises to raise aid spending are unlikely to be fulfilled. http://www.economist.com/node/17633128?story_id=17633128 Date of access: 26 Jan. 2011.

Economist print edition. 2010b. The millennium development goals: Global targets, local ingenuity.

http://www.economist.com/research/articlesBySubject/displaystory.cfm?subjectid=348915\&s tory_id=17090934 Date of access: 26 Jan. 2011.

Evans, A. 2006. Book review. The new conditionality: The politics of poverty reduction strategies. Development in practice. 16 (3/4): 372-374, June.

Fidelaar, V.M., Van meppelen scheppink, M.C. 1998. Venster op de wereld. Amsterdam: Buijten \& Schipperheijn. 
Goodwin, B. 2007. Using political ideas. West Sussex: John Wiley \& sons 1td.

Gordon, G. 2005. Indicators of poverty and hunger. http://www.un.org/esa/socdev/unyin/documents/ydiDavidGordon_poverty.pdf Date of access: 14 Feb. 2011.

Heywood, A. 2009. Politics. New York: Macmillan.

Investopedia. 2012. http://www.investopedia.com/terms/p/poverty-trap.asp Date of access: 12 Mar. 2012.

Isard, P., Lipschitz, L., Mourmouras, A., Yontcheva, B. 2006. The macroeconomic management of foreign aid: Opportunities and pitfalls. Washington: IMF Multimedia Services Division.

Iqbal, K., Shah, A. 2008. How do worldwide governance indicators measure up? http://siteresources.worldbank.org/PSGLP/Resources/Howdoworldwidegovernanceindicator smeasureup.pdf Date of access: 4 Jul. 2011.

Jackson, J., Jackson, D. 2003. An introduction to political science. Toronto: Prentice Hall.

Kaufman. 2010. Around the halls. The U.N.'s millennium development goals. http://www.brookings.edu/opinions/2010/0916_halls_mdg.aspx Date of access: 23 Oct. 2010.

Kahl, H. 2006. States, scarcity and civil strife in the developing world. New Jersey: Princeston University press.

Kotze, H. J., Van wyk, J. J. 1988. Politieke konsepte. Johannesburg: Perskor.

Logan, B. I., Mengisteab, K. 1995. Beyond economic liberalization in Africa: structural adjustment and the alternatives. London: ZED books.

McCormick, J. 2007. Comparative politics in transition. Belmont: Thomson.

McCormick, J. 2010. Comparative politics in transition. Belmont: Thomson.

Millenium development goals report. 2011. The millennium development goals report 2010. www.un.org/millenniumgoals/pdf/nl Date of access: 20 Oct. 2011.

Mavrotas, G. 2007. Scaling up foreign aid and the emerging new agenda. http://www.emeraldinsight.com/journals.htm?articleid=1784244\&show=pdf 211-233 Date of access: 12 Nov. 2010.

Ndungane, N. 2006. One year after the Gleneagles summit: Implementation, African development and the African monitor. (Lecture presented at the Center for global development on 13 July 2006.) Washington D.C. 4p. (Unpublished)

Sheperd. A. 2008. Achieving the MDGs: The fundamentals. http://www.odi.org.uk/resources/download/1933.pdf Date of access: 26 Oct. 2010.

Report on the United Nations conference on the environment and development. 2005. Resolutions adopted by the conference. http://en.wikipedia.org/wiki/Sustainable_development Date of access: 22 Mar. 2010.

Sachs, J.D., Mcarthur, W., Schmidt-traub, G., Kruk, M., Bahadur, C., Faye, M., Mcord, G. 2004. Ending Africa's poverty trap. 
http://www.unmillenniumproject.or/documents/BPEAEENDMAFRICASPOVERTYTR AP.pdf Date of access: 7 Mar. 2012.

Sachs, J.D. 2006. Investing in development: A practical plan to achieve the millennium development goals. London: Earthscan.

Sogge, D. 2002. Give and take: What's the matter with foreign aid? London: Cox \& Wyman.

Unescap. 2012. What is good governance? http://www.unescap.org/pdd/prs/ProjectActivities/Ongoing/gg/gov Date of access: 24 July 2012.

United Nations. 2010. Keeping the promise: United to achieve the millenium development goals. http://www.un.org/milleniumgoals/ Date of access: 20 Oct. 2010.

Uzor, O., O. 2009. Is it goodbye to foreign aid? The broker connecting worlds of knowledge. 14: 1-2p. May.

Van donge, J.K., Henley, D., Lewis, P. 2010. Tracking development in Southeast Asia and sub-Saharan Africa: The primacy of policy. www.trackingdevelopment.net Date of access: 14 Nov. 2010.

Vyas-Doorgapersad, S. 2010. The impact of global partnership for development (goal number 8) in achieving the millennium development goals in Africa. Africa insight. 40 (2): 40-53p. Sept.

World bank. 2011. Annual report 2011. Washington. World bank.

World hunger education service. 2011. 2012 World hunger and poverty facts and statistics. http://www.worldhunger.org/articles/Learn/worldhungerfacts2002htm Date of access: 21 Feb. 2012.

World development movement. 2010. Assessing the progress towards the Millennium Development Goals-goal by goal. http://www.wdm.org.uk/news/assessing-progress-towardsmillenium-development-goals-goal-by-goal Date of access: 25 Jan. 2011. 